Ключевые слова: конфликтологическая компетентность, будущие учителя иностранных языков, диагностические методики, комплексная методика диагностики.

POLISCHCHUK A. V. Complex methodology of diagnosis of conflictological competence of future teachers of foreign languages.

The article examines the features of pedagogical diagnostics, its difference from psychological diagnostics, and tips on the selection of diagnostic tools. According to a certain structure of conflictological competence, the next comprehensive diagnosis of the levels of formation of the phenomenon under study is proposed: a cognitive-reflective component - a methodology for studying interpersonal perception in a conflict situation (A. Tashchev as modified by A. Misenko) self-assessment of horizons by conflictology ( $S$. Kalaur) determination of the levels of formation of pedagogical reflection (A. Kalashnikova) value-motivational component - diagnosis of motivational orientations in interpersonal communications (I. Ladanov, V. Urazaeva) test "How tolerant are you?" (A. Tushkanov) "Expressdiagnostics of resistance to conflicts" (M. Fetiskin, V. Kozlov, G. Manuylov) corrective-operational component - test "Behavior style in a conflict situation" ( $K$. Thomas), methodology "Assessment of the level of competence in conflicts resolving” (P. Heppner, I. Petersen). An experimental study was conducted using the proposed integrated diagnosis, and its results has been analyzed by the author.

Keywords: conflictological competence, future teachers of foreign languages, diagnostic techniques, comprehensive diagnostic technique.

DOI: https://doi.org/10.31392/NZ-npu-145.2019.17

УДК [378.018.8:373.5011.3-051:62]:331.5

Потапкін В.

\title{
СПЕЦИФІКА РЕАЛІЗАЦІЇ МІЖПРЕДМЕТНИХ ЗВ'ЯЗКІВ У ПРОЦЕСІ ПРОФЕСІЙНОЇ ПІДГОТОВКИ МАЙБУТНІХ УЧИТЕЛІВ ТРУДОВОГО НАВЧАННЯ
}

У статті розглянуті питання оптимізації процесу професійної підготовки майбутніх учителів трудового навчання, які повинні оволодіти високим рівнем технічних, технологічних здібностей, інноваційного творчого мислення, оперування великими обсягами інформації, володіння методологією конструкторської діяльності. Одним із шляхів вирімення даного завдання є обтрунтування процесу реалізащії міжпредметних зв'язків під час вивчення дисииплін блоку професійної підготовки. Модель сучасного освітнього процесу підготовки майбутніх учителів трудового навчання може бути представлена як ієрархічна структура, елементами якої є одиниці навчального плану - дисципліни, щзо вивчаються.

Ключові слова: професійна підготовка, міжпредметні зв'язки, диференціація, інтеграція, дидактичні функиї міжпредметних зв 'язків, зв 'язок теорії і практики.

Зростаючі темпи модернізації виробництва, зміна змісту праці, потреби мобільного переходу від однієї професії до іншої в умовах сучасного динамічного розвитку виробництва, виникнення нових професій значно підвищили вимоги до рівня підготовки майбутніх учителів трудового навчання. А це, в свою чергу, актуалізувало потребу взаємоузгодженого вивчення 
загальноосвітніх, загальнотехнічних та спеціальних дисциплін. Не дивлячись на те, що в дидактиці професійної освіти напрацьований вагомий досвід щодо практичної реалізації міжпредметних зв'язків у освітньому процесі, у багатьох педагогів виникають значні труднощі в організації навчання на міжпредметній основі.

Поряд із теоретичним розумінням сутності міжпредметних зв'язків винятково важливим $€$ питання їхньої практичної реалізації. Відповідно, виникає необхідність у визначенні і реалізації оптимального поєднання процесів диференціації та інтеграції дисциплін, які входять до навчального плану з підготовки майбутніх учителів трудового навчання.

Аналіз останніх досліджень і публікацій показав, що над різними проблемами профресійної підготовки майбутніх учителів трудового навчання в Україні активно працювали Д. Тхоржевський, В. Сидоренко, О. Коберник, С. Ткачук, А. Терещук та ряд інших дослідників. Як свідчать публікації у фахових виданнях, виступи на науково-практичних семінарах і конференціях, такі дослідження продовжуються. Але при всьому цьому слід зазначити, що питанням оптимізації освітнього процесу майбутніх учителів трудового навчання засобами міжпредметних зав'язків приділено недостатньо уваги.

Метою статті $€$ аналіз можливості оптимізації процесу професійної підготовки майбутніх викладачів практичного навчання на основі реалізації дидактичних функцій міжпредметних зв'язків, розширення сфери практичного застосування знань, умінь і навичок, аналізу джерел мотивації навчальної діяльності студентів.

Процес професійної підготовки майбутнього вчителя трудового навчання нерозривно пов'язаний зі змінами, що відбуваються в системі загальної середньої освіти. Відповідно, нами було проведено аналіз досліджень 3 проблеми реалізації міжпредметних зв'язків на рівні основної школи. Встановлено, що специфіка встановлення і реалізації міжпредметних зв'язків в освітньому процесі основної школи зумовлена передусім:

1) необхідністю забезпечення загальної середньої освіти, спрямованої на різнобічний розвиток особистості, зокрема, на фрормування її моральної інтелектуальної, естетичної, трудової та фрізичної культури, індивідуальних якостей, світогляду, ерудиції, здійснення професійної орієнтації, розвиток індивідуальності з урахуванням інтересів, здібностей та якостей школяра;

2) наявністю лише загальноосвітніх дисциплін;

3) гармонійним співвідношенням між предметами природничоматематичного і гуманітарного циклів, а також наявністю дисциплін художньоестетичного, фізичного та трудового спрямування, що забезпечує відносну рівноправність усіх навчальних дисциплін щодо мети і завдань загальної освіти;

4) класно-урочною фрормою організації навчання;

5) наявністю учнів різних вікових категорій;

6) професійною невизначеністю частини випускників;

7) викладанням одним учителем, як правило, не більше 1 або 2 споріднених навчальних предметів і відсутністю потреби (на думку 
переважної більшості з них) вникати в проблеми методики викладання інших дисциплін;

8) відсутністю практичної підготовки учнів (якщо не брати до уваги лабораторних і практичних робіт з окремих предметів), що забезпечує превалювання теоретичного навчання;

9) переважанням пояснювально-ілюстративних та репродуктивних методів навчання;

10) широкими можливостями для позаурочної та позакласної навчальної і виховної роботи.

Ми вважаємо, що головною метою реалізації міжпредметних зв'язків у закладах середньої освіти. $є$ актуальна потреба фрормування у свідомості учнів єдиної загальнонаукової картини світу. Це зумовлено, передусім, вимогами гуманізації та гуманітаризації освіти. Адже, як відомо, педагогічний процес у сучасній школі давно перетворився на сукупність практично не пов'язаних між собою пізнавальних процесів з різноманітних дисциплін, керований різними вчителями. Деякий виняток становлять тут лише окремі заклади альтернативної освіти - спеціалізовані гімназії, ліцеї, приватні заклади загальної середньої освіти. Зміст освіти і методика викладання в цих навчальних закладах підпорядковується ідеї поглибленого профільного навчання, а тому $€$ предметом більш ґрунтовного педагогічного аналізу і наукового пошуку педагогічних кадрів. Внаслідок цього й забезпечується значно краща результативність навчання й розуміння причинно-наслідкових зв'язків між окремими явищами.

Проте й у школах нового типу на сучасному етапі надзвичайно гостро постає проблема оптимального поєднання гуманітарних і природничоматематичних дисциплін. У змісті й організації освітнього процесу в цих закладах освіти переважає дія принципу диференціації. У окремих ліцеях, наприклад, поглиблено вивчаються предмети природничо-математичного циклу, а тому ліцеїсти не зорієнтовані на отримання ґрунтовної гуманітарної освіти. У гуманітарних гімназіях, навпаки, недостатня увага приділяється вивченню математики, фрізики, хімії, біології, інформатики. 3 метою розв'язання цієї суперечності необхідні пошуки різних методик, тому важливо узагальнити науково-педагогічні дослідження, в яких, на нашу думку, відображені загальні тенденції розвитку поглядів учених на зміст, структуру, фрорми організації міжпредметного навчання в умовах сучасної основної школи. Розглянемо деякі з них.

Так, І. Звєрєв, О. Гузєєв, В. Медведєв вивчали проблеми координації та інтеграції змісту освіти, ефективної реалізації міжпредметних зв'язків на основі тематичного і хронологічного узгодження навчальних програм; П. Третьяков, А. Усова займалися визначенням умов, необхідних для систематичного здійснення міжпредметних зв'язків; М. Білий, Л. Орлова - з'ясуванням методичних можливостей навчання учнів реалізації міжпредметних зв'язків [1, 5].

Праці М. Голобородько, Ф. Соколової, Л. Загрекової, Є. Клоса, Л. Резнікова, В. Тевліна, Л. Уфімцева, Б. Яворського присвячені розкриттю особливостей формування цілісних наукових понять та підвищення наукового 
рівня знань на основі здійснення багатопредметних і багатосторонніх зв'язків. Інші вчені (В. Ільченко, В. Максимова, С. Рашкова та ін.) обгрунтували важливість використання загальних законів природи як основи узагальнення й систематизації знань учнів з різних предметів, об'єднання їх у систему навколо однієї міжпредметної проблеми або об'єкту [1].

У дослідженнях О. Мацієвського, О. Анічкіної розглядається комплексний підхід до реалізації міжпредметних зв'язків під час вивчення відповідних тем у суміжних дисциплінах. Розробкою математичних моделей міжпредметних зв'язків займалися М. Голобородько, А. Пінський та ін. [66, 72].

Методологічну систему формування екологічних знань на основі міжпредметного підходу розробляли Л. Вороніна, Т. Каленнікова, В. Назаренко, Н. Пустовіт, Л. Руденко та ін. С. Бабаджанян, В. Монахов, П. Кулагін досліджували напрямки, зміст, методи і прийоми реалізації міжпредметних зв'язків у позакласній роботі, а також у вечірній школі [1].

Зазначимо, що загалом основні ідеї щодо практичної реалізації міжпредметних зв'язків, сформульовані у згаданих вище дослідженнях, можуть використовуватися вчителями в освітньому процесі. Проте, більшість цих ідей (зокрема: проблеми координації та інтеграції змісту освіти, розкриття особливостей формування цілісних наукових понять та підвищення наукового рівня знань учнів на основі встановлення багатосторонніх зв'язків, комплексний підхід до реалізації міжпредметних зв'язків під час вивчення відповідних тем у суміжних дисциплінах, розробка математичних моделей міжпредметних зв'язків тощо) потребують певної адаптації до нових умов, врахування інваріантної та варіативної частин змісту загальної середньої освіти, поєднання з іншими педагогічними технологіями навчання.

Реалізація міжпредметних зв'язків у закладах вищої освіти, хоча й відповідає тим закономірностям, які спостерігаються основній школі, проте має деякі специфічні відмінності, що визначаються змістом вищої освіти.

Науковцями встановлені взаємозв'язки технічних дисциплін, вивчений процес управління освітньою діяльністю студентів при різних фрормах організації навчання, досліджена ефективність розробленого процесу реалізації взаємозв'язку технічних дисциплін для підвищення якості підготовки майбутніх вчителів.

У праці Д.Тхоржевського [5] в результаті аналізу змісту навчального матеріалу й навчального процесу на факультетах підготовки вчителів трудового навчання виділені та класифіковані закономірні зв'язки між навчальними дисциплінами технічного циклу; описані різні способи здійснення міжпредметних зв'язків; наведені етапи, дидактичні рівні та конкретні приклади організації пізнавальної діяльності студентів при здійсненні міжпредметних зв'язків.

Як ми вже зазначали вище, під час вивчення окремих дисциплін в умовах багатопредметної структури змісту освіти у закладах вищої освіти виникає певна небезпека ізольованості знань у свідомості студентів. Це зумовлює необхідність оптимального поєднання процесів диференціації та інтеграції.

Процес інтеграції розглядають як взаємопроникнення, взаємовплив, 
взаємозв'язок змісту різних навчальних предметів з метою фрормування у студентів комплексної, діалектично взаємозв'язаної системи наукових знань про навколишній світ або суспільне життя [1]. Інтеграційні явища в освітньому процесі спостерігаються у формі стихійної або керованої інтеграції. У випадку стихійної інтеграції студент самостійно без допомоги викладача використовує знання й уміння, які він здобув під час вивчення інших дисциплін. Основним дидактичним інструментом керованої інтеграції виступають міжпредметні зв'язки [6]. Вони передбачають, з одного боку, диференціацію навчальних дисциплін з урахуванням особливостей кожної 3 них, а 3 другого - їхню інтеграцію.

Характеристика концептуальних підходів до розуміння категоріальної сутності та загальних функцій міжпредметних зв'язків детально розкривають їх призначення і роль в освітньому процесі різних закладів освіти. 3 огляду на це, окреслимо значущість міжпредметних зв'язків у закладах вищої освіти, оскільки:

- здійснення міжпредметних зв'язків сприяє реалізації основних дидактичних принципів (виховуючого навчання, науковості, професійної спрямованості, зв'язку теорії з практикою, з життям, свідомості та активності, доступності, систематичності та послідовності, міцності, наочності та ін.);

- реалізація міжпредметних зв'язків передбачає координацію дисциплін та узгодження навчальних програм, що забезпечує наступність і неперервність у навчанні, максимально виключає недоцільне дублювання матеріалу, створює резерв часу для більш ґрунтовного і міцного засвоєння студентами провідних ідей наук;

- комплексний підхід до реалізації міжпредметних зв'язків забезпечує подолання розрізненості знань, умінь та навичок студентів в умовах багатопредметної системи навчання; сприяє підвищенню рівня мобільності знань і умінь студентів (тобто їх здатності переносити засвоєну навчальну інформацію з однієї дисципліни в іншу, з однієї ситуації - в нову, а також використовувати їх у нестандартних умовах);

- значно посилюється професійна спрямованість навчання, що забезпечує удосконалення практичної підготовки, спонукає студентів до розв'язання наукових, виробничих, соціальних, економічних, екологічних, суспільно-політичних проблем з метою успішного оволодіння обраним фахом; суттєво підвищує інтерес до навчання, підсилюючи внутрішні мотиви до навчальної діяльності (пізнавальної, практичної, фрахової, ціннісноорієнтаційної тощо);

- стимулювання та розвиток у студентів уваги, пам'яті, загальних розумових операцій (синтезу і аналізу, індукції та дедукції, уміння порівнювати, конкретизувати, узагальнювати, систематизувати, виділяти головне, абстрагувати), що спостерігається під час застосування знань, умінь і навичок з різних дисциплін, підвищує рівень самостійності студентів у здобутті ними нових знань та вмінь, активізує творчий пошук.

На наш погляд, специфіка реалізації міжпредметних зв'язків у навчальновиховному процесі закладів вищої освіти, зумовлена: 
1) потребою підготовки висококваліфрікованого фахівця;

2) умовами й вимогами ступеневої системи освіти, яка актуалізує потребу реалізації внутрішньонаукових і міжнаукових зв'язків адекватно принципам наступності та послідовності;

3) реалізацією принципу політехнічного навчання (у випадку підготовки фрахівців профрсійної та технологічної освіти);

4) наявністю циклів гуманітарних та соціально-економічних, фундаментальних і професійно-зорієнтованих дисциплін, практичного навчання (це спричинює необхідність реалізації міжпредметних зв'язків, серед яких можна виділити попередні зв'язки зі шкільними предметами та різнопланові внутрішньоциклові і міжциклові взаємозв'язки навчальних дисциплін);

5) пріоритетною роллю професійно-зорієнтованих дисциплін у системі навчальних курсів і спецкурсів (дисципліни спеціалізації забезпечують формування фрахових знань та вмінь, їх успішне використання у практичній діяльності, виконання виробничих фрункцій);

6) професійною спрямованістю соціально-економічних та природничоматематичних дисциплін (основи цих предметів викладаються в необхідному обсязі, проте їх вивчення направлене на фрормування фрахових знань, умінь $\mathrm{i}$ навичок студентів);

7) поділом змісту профресійної освіти на теоретичну і практичну підготовки (теоретична підготовка передбачає, здебільшого, формування фрахових знань та вмінь, а практична - формування фрахових умінь і навичок під час проходження різних видів практики відповідно до профрілю);

8) необхідністю узгодженої взаємодії всіх викладачів та майстрів виробничого навчання (така взаємодія необхідна для ефективної реалізації міжпредметних зв'язків між дисциплінами, що забезпечують теоретичну підготовку, і практичним навчанням);

9) веденням одним викладачем кількох навчальних курсів;

10) переважанням традиційних для закладів вищої освіти організаційних форм навчання (лекцій, практичних, лабораторних та семінарських занять) та значно ширшою можливістю проведення нестандартних занять (у формі ділової гри, наукових конференцій, комп'ютерних та інтегрованих занять, різних видів екскурсій на виробництво, у дослідні господарства тощо);

11) тривалістю навчальних занять (лекційні, семінарські заняття - 90 хв, практичні та лабораторні заняття - 90 хв і більше);

12) пріоритетним значенням самостійної роботи студентів у системі інших форм організації навчання, а також таких фрорм організації навчання, як науково-пошукові та курсові роботи, дипломні проекти, творчі завдання, ресрерати тощо;

13) ефрективністю індивідуальної роботи зі студентами (консультації, додаткові заняття, конфреренції, інструктажі тощо);

15) необхідністю забезпечення різнобічного розвитку особистості майбутнього фрахівця, фрормування його моральної, інтелектуальної, естетичної, професійної та фізичної культури, комунікативних професійних 
якостей, професійної самосвідомості, світогляду, ерудиції, розвиток індивідуальності з урахуванням здібностей студента;

16) наближенням тематики виховної роботи до проблем професійної підготовки фахівця (розгляд проблем професійної етики, психології спеціаліста, адаптації його до школи, формування фрахової екологічної культури тощо).

Висновок. Підсумовуючи, зауважимо, що реалізація міжпредметних зв'язків у освітньому процесі закладів вищої освіти має певну специфіку, що суттєво відрізняється від особливостей їх здійснення в основній школі. Отже, виникає необхідність забезпечення умов міжпредметного навчання у закладах вищої освіти, пошуку шляхів підвищення його ефективності.

Саме тому модель сучасного освітнього процесу з підготовки майбутнього вчителі трудового навчання може бути представлена як ієрархічна структура, елементами якої є одиниці навчального плану - дисципліни, що вивчаються. Навчити студента усвідомлювати факт цілісності такої системи, вмінню переносити знання як всередині блоків фундаментальної інженерної бази, так і при креативному вирішенні виробничих завдань, переходу від управління знаннями до генерації знань - це завдання, що стоїть перед кожним гарантом відповідної освітньої програми, членом робочої групи та кожним викладачем.

\section{Актуальними напрямками подальшої розробки окреслюваної} проблеми є вивчення питання раціонального використання систем автоматизованого проектування в процесі реалізації міжпредметних зв'язків під час професійної підготовки майбутніх учителів трудового навчання.

\section{Використана література:}

1. Сидоренко В. К. “Технологія” як об’єкт термінотворення для виправданої назви освітньої галузі. Збірник наукових пращь Полтавського держсавного педагогічного університету iм. В. Г. Короленка. Серія "Педагогічні науки". 2004. Випуск 3. С. 114-122.

2. Стешенко В. В. Зміст трудового навчання (технологій) на наукову основу. Трудова підготовка в сучасній школі. 2013. № 3. С. $2-4$.

3. Теорія і методика навчання технології : навч. посіб. / за заг. ред. О. М. Коберника. Умань : ФОП Жовтий, 2014. 480 с.

4. Терещук А. І., Дятленко С. М. Методика організації проектної діяльності старшокласників 3 технологій : метод. посібник. Київ : Літера ЛТД, 2010. 128 с.

5. Тхоржевський Д. О. Дидактика трудового навчання. Київ : Рідна шк., 1972. 162 с.

6. Школа майбутнього як інноваційний заклад освіти : наук. метод. посібник / В. М. Мадзігон, Л. М. Ващенко, Л. І. Даниленко та ін. ; за ред. В. М. Мадзігона. Київ, 2010. 144 с.

\section{References:}

[1] Sydorenko V. K. "Tekhnolohiia" yak obiekt terminotvorennia dlia vypravdanoi nazvy osvitnoi haluzi. Zbirnyk naukovykh prats Poltavskoho derzhavnoho pedahohichnoho universytetu im. V. H. Korolenka. Seriia "Pedahohichni nauky". 2004. Vypusk 3. S. 114-122.

[2] Steshenko V. V. Zmist trudovoho navchannia (tekhnolohii) na naukovu osnovu. Trudova pidhotovka $v$ suchasnii shkoli. 2013. № 3. S. 2-4.

[3] Teoriia i metodyka navchannia tekhnolohii : navch. posib. / za zah. red. O. M. Kobernyka. Uman : FOP Zhovtyi, 2014. $480 \mathrm{~s}$.

[4] Tereshchuk A. I., Diatlenko S. M. Metodyka orhanizatsii proektnoi diialnosti starshoklasnykiv z tekhnolohii : metod. posibnyk. K. : Litera LTD, 2010. 128 s.

[5] Tkhorzhevskyi D. O. Dydaktyka trudovoho navchannia. K. : Ridna shk., 1972. 162 s. 
[6] Shkola maibutnoho yak innovatsiinyi zaklad osvity : nauk. metod. posibnyk / V. M. Madzihon, L. M. Vashchenko, L. I. Danylenko ta in. ; za red. V. M. Madzihona. K., 2010. 144 s.

ПотАПкин В. Специфика реализации межспредметных связей в процессе профессиональной подготовки будущих учителей трудовой подготовки.

В статье рассмотренные вопросы оптимизации проиесса профессиональной подготовки будуших учителей трудовой подготовки, которые должны завладеть высоким уровнем технических, технологических способностей, инновационного творческого мылиления, оперирования большими объемами информации, обладания методологией конструкторской деятельности. Одним из путей решения данного задания есть обоснование процесса реализации межпредметных связей во время изучения дисциплин блока профессиональной подготовки. Модель современного образовательного прочесса подготовки будущии учителей трудовой подготовки может быть представлена как иерархическая структура, элементами которой являются единицы учебного плана - дисииплины, которые изучаются.

Ключевые слова: профессиональная подготовка, межпредметные связи, дифференциация, интеграчия, дидактичные функции межпредметных связей, связь теории и практики.

POTAPKIN VITALII. Specifics of the realization of interdisciplinary connections in the process of professional training of future teachers of labour training.

The article deals with the optimization of the process of professional training of future teachers of labour training, who must obtain a high level of technical, technological abilities, innovative creative thinking, managing large amounts of information, knowing design activity methodology. One of the ways to solve this problem is to justify the process of realization of interdisciplinary connections during the study of the disciplines of a professional training block.

It has been determined that the main purpose of the realization of interdisciplinary connections is an urgent need to form unified general scientific picture of the world in students' consciousness. It is determined, primarily, by the requirements of humanization and humanitarization of education. An educational process in a modern institution of higher education should not be transformed into a set of unrelated cognitive processes in different disciplines, managed by different teachers.

It has been determined that the basic ideas concerning a practical realization of interdisciplinary connections (in particular: problems of coordination and integration of the content of education, the description of peculiarities of holistic scientific concepts formation and the increase of scientific level of students' knowledge on the basis of many-sided relations establishment, a complex approach to the realization of interdisciplinary connections while studying relevant themes in related disciplines, developing mathematical models of interdisciplinary connections, etc.) require an adaptation to new conditions, taking into account invariant and variable parts of general secondary education content, the combination with other educational technologies.

The model of a modern educational process of future teachers of labour training may be represented as a hierarchical structure, the elements of which are curriculum units - disciplines being studied. The realization of interdisciplinary connections involves the coordination of disciplines and curricula, which ensures sequence and continuity in learning, eliminates inappropriate material duplication, provides time for more thorough understanding of leading scientific ideas by students.

Keywords: vocational training, cross-curricular relations, differentiation, integration, didactic functions of cross-curricular relations, theory and practice connection. 